\title{
ANORECTAL MANOMETRY IN CHILDREN WITH CHRONIC FUNCTIONAL CONSTIPATION
}

\author{
Rosa Helena Monteiro BIGÉLLI, Maria Inez Machado FERNANDES, \\ Yvone Avalloni de Moraes Villela de Andrade VICENTE, Roberto Oliveira DANTAS, \\ Lívia Carvalho GALVÃO and Antônio Dorival CAMPOS
}

ABSTRACT - Background - The anorectal manometry is a very utilized and well recognized examination in children with chronic funcional constipation. The major manometric findings in these children are: anal hypotonia, anal hypertonia, paradoxal contraction of the external anal sphincter, decreased ability of internal anal sphincter to relax during rectal distension and alterations in rectal contractility, sensibility and compliance. Aims - To evaluate the anal basal pressure and the relaxation reflex before and after standard treatment for a better understanding of the physiopathologic mechanisms involved in pediatric chronic functional constipation. Methods - Anorectal manometry was performed before treatment on 20 children with chronic functional constipation aged 4 to 12 years and the results were compared to those obtained after standard treatment, with a good outcome. Results - There was a reduction in anal basal pressure after treatment, but no differences were detected between the anorectal manometries performed before and after treatment in terms of amplitude and duration of relaxation, residual pressure, latency time, or descent and ascent angle. Conclusions - We conclude that the anal basal pressure decreased in children recovering from chronic functional constipation, but the standard treatment did not provide all the conditions necessary for the relaxation reflex of constipated children to return to the values described in normal children.

HEADINGS - Manometry. Constipation. Rectum, physiology. Anus, physiology. Children.

\section{INTRODUCTION}

Chronic functional constipation represents $95 \%$ of the cases of pediatric constipation. Its pathophysiologic mechanisms have being studied by anorectal manometry ${ }^{(10)}$.

In children with chronic functional constipation, the major manometric findings are: anal hypertonia ${ }^{(12,13)}$, anal hypotonia $^{(5,6,7)}$, paradoxical contraction of the external anal sphincter ${ }^{(8)}$, decreased ability of the internal anal sphincter to relax during rectal distension ${ }^{(5)}$, increased rectal compliance, decreased conscious rectal sensitivity, and decreased rectal contractility ${ }^{(11,12)}$.

In view of the scarcity of studies demonstrating how the anal sphincter acts in children with chronic functional constipation and showing the influence of standard treatment on its activity, the present study was carried out to assess anal basal pressure and the relaxation reflex before and after standard treatment for a better understanding of the pathophysiological mechanisms involved in pediatric chronic functional constipation. The major objectives of the present study were: 1) to standardize the methodology of anorectal manometry at our Institution, 2) to study the activity of anal sphincter in children aged 4 to 12 years with chronic functional intestinal constipation with a good outcome after standard treatment, and 3) to compare the manometric parameters evaluated before and after treatment in these children in order to determine possible changes induced by standard treatment.

\section{PATIENTS AND METHODS}

The study was approved by the Medical Ethics Committee of the University Hospital, Faculty of Medicine of Ribeirão Preto, University of São Paulo, Ribeirão Preto, SP, Brazil. A written informed consent was obtained from the parents. The study was conducted on children with chronic functional constipation seen at the Pediatric Gastroenterology Unit of this hospital.

Inclusion criteria: children aged 4-12 years, with stool frequency of $<3$ per week or the painful passage of bowel movements and stool retention with or without soiling even when the stool frequency was $>3$ per week for at least 1 month.

Exclusion criteria: children with organic constipation, gastroenterologic and chronic debilitating diseases, mental deficiency and neurological abnormalities.

Study: the selected children were submitted to detailed anamnesis and physical examination, barium enema and anorectal manometry, and then to standard treatment

Department of Pediatrics of Faculty of Medicine of Ribeirão Preto, University of São Paulo, Ribeirão Preto, SP, Brazil

Address for correspondence: Dr. Maria Inez Machado Fernandes - Department of Pediatrics - Faculty of Medicine of Ribeirão Preto - University of São Paulo - Avenida Bandeirantes, 3900 - 14049-900 - Ribeirão Preto, SP, Brazil. E-mail: mimferna@fmrp.usp.br 
for a period of 6 months. At the end of treatment, anorectal manometry was repeated in children with a good outcome and the results were compared with those obtained on the occasion of the first manometry.

Manometric procedure: the manometries were realized without sedation. All children received one phosphate enema, $10 \mathrm{~mL} / \mathrm{kg}$ (maximum $120 \mathrm{~mL}$ ), at least $1 \mathrm{~h}$ before the study. At the first manometry, when fecal retention was important the children required one phosphate enema a day from 3 to 7 days. A manometric anal probe $2.4 \mathrm{~mm}$ in outer diameter and $1 \mathrm{~mm}$ in inner diameter was used. Two side holes spaced $1.6 \mathrm{~cm}$ apart were perfused with sterile water at a rate of $0.25 \mathrm{~mL} / \mathrm{min}$ using a hydraulic infusion system constructed in this service. A latex rectal distending balloon with a high compliance was tied to the tip of the probe $4.5 \mathrm{~cm}$ above the first side hole. Pressures were measured by transducers situated in each perfusion line and connected to the Physiograph MK-IV Polygraph, Narco Bio-Systems (Narco Scientific, Houston, Texas, USA), where the tracing of the recording with the highest anal resting pressure was obtained on paper. During the study patients were instructed to lie on their right side. The anal basal pressure was determined by the station pull-through technique.

Manometric parameters studied: anal basal pressure (ABP), amplitude (AR) and duration (DR) of relaxation, residual pressure (RP), latency time (LT), and descent (DA) and ascent (AA) angle. The anal basal pressure is the average of all averages between the lowest and the highest points for each interval included between the end of one relaxation and the beginning of the next, for the same volume. These parameters were studied in the " 1 - second rectal distention" the stimuli were applied and removed) and the "10- second rectal distention" (the stimuli were applied for 10 seconds and removed) by insufflating the rectal balloon with $10,20,30,40$ and $50 \mathrm{~mL}$ of air, each volume for twice (Figures 1, 2).

Standard treatment: treatment consisted of education (all parents and children were informed that the defecation problem was caused by the underlying chronic constipation and that they were not to blame), fecal disimpaction (one tube of sorbitol administered intrarectally for 3 days), prevention of future impaction and promotion of regular bowel habits (dietary fiber and $1 \mathrm{a} 2 \mathrm{~mL} / \mathrm{kg}$ /day of mineral oil, once a day, with the laxative dose being gradually decreased when the children maintained one bowel movement a day), and finally toilet training (the children were encouraged to sit on the toilet for up to $5 \mathrm{~min}$, twice a day, after meals). They were considered children with good outcome when after 6 months of treatment for at least 1 month they were being off laxatives, with stool frequency of $\geq 3$ per week, painless passage of bowel movements and absence of stool retention or soiling.

Statistical methods: data were analyzed statistically by the Fisher exact probability test, the Wilcoxon unpaired rank sum test, the Friedman test and the multiple comparison test, with the level of significance set at $5 \%$.

\section{RESULTS}

Of the 39 children admitted to the study, 5 abandoned it and 34 completed it (median age: 7 years and 1.5 months; 17 boys). Among the 34 children, 22 (64.7\%) had a good treatment outcome and $12(35.3 \%)$ a poor outcome.

There were no differences between the group with good outcome and the group with poor outcome in terms of a family history of constipation, previous urinary tract infection, presence of feces in the rectum or normal barium enema. However, there was a significant difference in fecal soiling which was observed in $59 \%$ of the patients with a good outcome and in $100 \%$ of the patients with a poor outcome, before treatment.

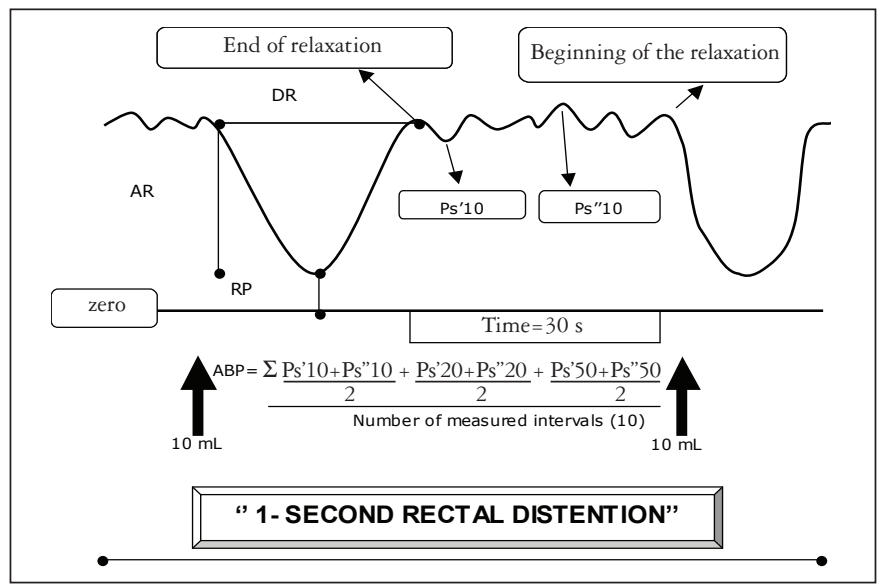

FIGURE 1 - Representation of a manometric study. There are two relaxation reflexes after the insufflation of the rectal balloon with 10 $\mathrm{mL}$ of air during the 1 - second rectal distention. The time between the end of one relaxation and the beginning of the next was $30 \mathrm{~s}$. The figure shows the points indicating the beginning and the end of the relaxation, the lowest ( $\left.\mathrm{Ps}^{\prime}\right)$ and the highest points (Ps"), the amplitude (AR) and the duration of the relaxation (DR), and the residual pressure (RP)

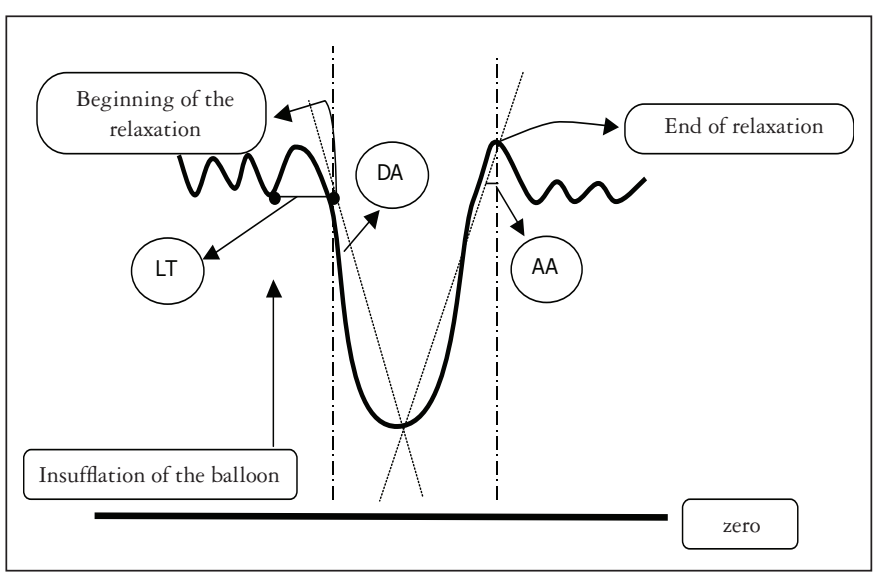

FIGURE 2 - Representation of a relaxation reflex. The beginning and the end of the relaxation, the latency time (LT), the descent (DA) and the ascent (AA) angles are observed, after the insufflation of the rectal balloon 


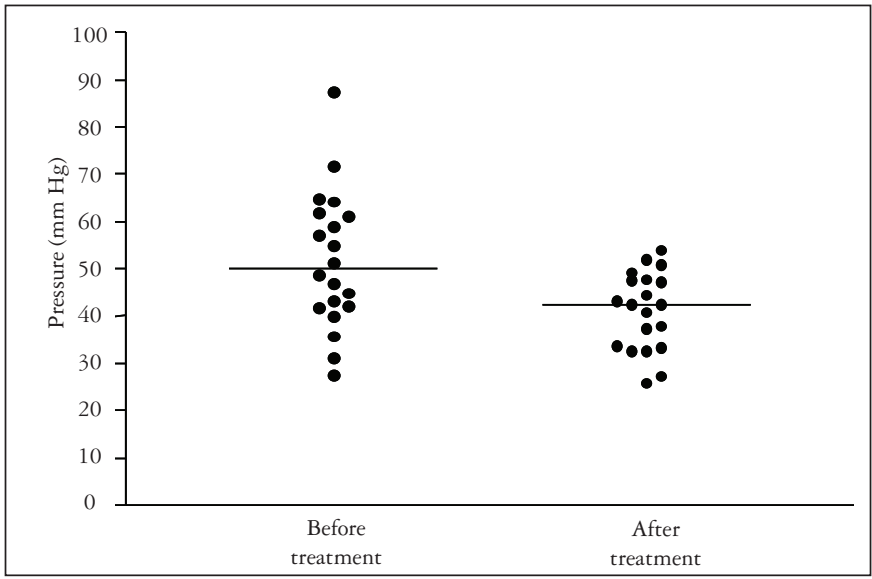

FIGURE 3 - Distribution of 20 children with good outcome in terms of the basal pressure in the internal anal sphincter, before and after treatment

- The horizontal bars represent the median

- Wilcoxon test $(P=0.007)$
There was a reduction in median anal basal pressure after treatment (before treatment $=50 \mathrm{~mm} \mathrm{Hg}$ and after treatment $=43 \mathrm{~mm} \mathrm{Hg}, P=0.007$ ) (Figure 3). The percentage of the insufflations of the rectal balloon that resulted in relaxation reflex during the 1- second rectal distention were [median (range)], $100 \%(60 \%-100 \%)$ before treatment and 100\% (70\%-100\%) after treatment. During the 10- second rectal distention, the results were $85 \%(60 \%-100 \%)$ before treatment and $100 \%$ (60\%-100\%) after treatment $(P>0,05)$. Analysis of the results obtained for anorectal manometry before and after treatment in 20 children with a good outcome showed no difference in the amplitude and the duration of the relaxation, residual pressure, latency time or ascent and descent angle when " 1 and 10- second rectal distentions" of the pretreatment anorectal manometry, the " 1 and 10 - second rectal distentions" of the after treatment anorectal manometry, "1- second rectal distentions" of the pretreatment anorectal manometry and "10- second rectal distentions" of the after treatment anorectal manometry were compared $(P>0,05)$ (Tables 1, 2).

TABLE 1 - Median and range of manometric parameters for 20 children with good outcome, with insufflations of the rectal balloon from 10 to 50 $\mathrm{mL}$ of air, before and after treatment, "1- second rectal distention"

\begin{tabular}{|c|c|c|c|c|c|c|c|c|c|c|}
\hline & \multicolumn{5}{|c|}{ Before treatment } & \multicolumn{5}{|c|}{ After treatment } \\
\hline & $10 \mathrm{~mL}$ & $20 \mathrm{~mL}$ & $30 \mathrm{~mL}$ & $40 \mathrm{~mL}$ & $50 \mathrm{~mL}$ & $10 \mathrm{~mL}$ & $20 \mathrm{~mL}$ & $30 \mathrm{~mL}$ & $40 \mathrm{~mL}$ & $50 \mathrm{~mL}$ \\
\hline $\begin{array}{l}\text { Amplitude of } \\
\text { relaxation }(\mathrm{mmHg})\end{array}$ & $\begin{array}{c}21 \\
(14-39)\end{array}$ & $\begin{array}{c}30 \\
(6-47)\end{array}$ & $\begin{array}{c}32 \\
(13-54)\end{array}$ & $\begin{array}{c}36 \\
(12-51)\end{array}$ & $\begin{array}{c}38 \\
(10-56)\end{array}$ & $\begin{array}{c}21 \\
(6-28)\end{array}$ & $\begin{array}{c}23 \\
(9-48)\end{array}$ & $\begin{array}{c}30 \\
(13-48)\end{array}$ & $\begin{array}{c}35 \\
(12-55)\end{array}$ & $\begin{array}{c}36 \\
(11-59)\end{array}$ \\
\hline $\begin{array}{l}\text { Duration of } \\
\text { relaxation (s) }\end{array}$ & $\begin{array}{c}9 \\
(2-14)\end{array}$ & $\begin{array}{c}11 \\
(2-17)\end{array}$ & $\begin{array}{c}12 \\
(5-19)\end{array}$ & $\begin{array}{c}13 \\
(9-35)\end{array}$ & $\begin{array}{c}13 \\
(10-34)\end{array}$ & $\begin{array}{c}8 \\
(2-18)\end{array}$ & $\begin{array}{c}10 \\
(6-16)\end{array}$ & $\begin{array}{c}13 \\
(6-18)\end{array}$ & $\begin{array}{c}13 \\
(7-24)\end{array}$ & $\begin{array}{c}15 \\
(8-31)\end{array}$ \\
\hline $\begin{array}{l}\text { Residual pressure } \\
(\mathrm{mmHg})\end{array}$ & $\begin{array}{c}25 \\
(6-42)\end{array}$ & $\begin{array}{l}20 \\
(4-36)\end{array}$ & $\begin{array}{c}16 \\
(3-38)\end{array}$ & $\begin{array}{c}17 \\
(4-43)\end{array}$ & $\begin{array}{c}21 \\
(5-42)\end{array}$ & $\begin{array}{c}14 \\
(5-32)\end{array}$ & $\begin{array}{c}10 \\
(0-38)\end{array}$ & $\begin{array}{c}7 \\
(0-27)\end{array}$ & $\begin{array}{c}7 \\
(0-24)\end{array}$ & $\begin{array}{c}7 \\
(0-24)\end{array}$ \\
\hline Latency time (s) & $\begin{array}{c}2 \\
(0-2)\end{array}$ & $\begin{array}{c}2 \\
(0-4)\end{array}$ & $\begin{array}{c}1 \\
(0-3)\end{array}$ & $\begin{array}{c}1 \\
(0-5)\end{array}$ & $\begin{array}{c}1 \\
(0-2)\end{array}$ & $\begin{array}{c}2 \\
(0-4)\end{array}$ & $\begin{array}{c}2 \\
(0-3)\end{array}$ & $\begin{array}{c}1 \\
(0-3)\end{array}$ & $\begin{array}{c}1 \\
(0-4)\end{array}$ & $\begin{array}{c}1 \\
(0-3)\end{array}$ \\
\hline Descent angle ${ }^{(0)}$ & $\begin{array}{c}37 \\
(17-53)\end{array}$ & $\begin{array}{c}32 \\
(21-59)\end{array}$ & $\begin{array}{c}35 \\
(17-59)\end{array}$ & $\begin{array}{c}31 \\
(21-60)\end{array}$ & $\begin{array}{c}35 \\
(20-61)\end{array}$ & $\begin{array}{c}34 \\
(8-64)\end{array}$ & $\begin{array}{c}34 \\
(15-50)\end{array}$ & $\begin{array}{c}35 \\
(22-62)\end{array}$ & $\begin{array}{c}32 \\
(21-69)\end{array}$ & $\begin{array}{c}31 \\
(17-57)\end{array}$ \\
\hline Ascent angle ${ }^{(0)}$ & $\begin{array}{c}48 \\
(25-65)\end{array}$ & $\begin{array}{c}49 \\
(32-64) \\
\end{array}$ & $\begin{array}{c}48 \\
(31-63) \\
\end{array}$ & $\begin{array}{c}52 \\
(37-73) \\
(3)\end{array}$ & $\begin{array}{c}57 \\
(28-75) \\
\end{array}$ & $\begin{array}{c}49 \\
(21-71)\end{array}$ & $\begin{array}{c}56 \\
(27-74)\end{array}$ & 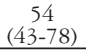 & $\begin{array}{c}54 \\
(40-84) \\
\end{array}$ & $\begin{array}{c}54 \\
(36-83) \\
\end{array}$ \\
\hline
\end{tabular}

TABLE 2 - Median and range of manometric parameters for 20 children with good outcome, with insufflations of the rectal balloon from 10 to $50 \mathrm{~mL}$ of air, before and after treatment, "10- second rectal distention"

\begin{tabular}{|c|c|c|c|c|c|c|c|c|c|c|}
\hline & \multicolumn{5}{|c|}{ Before treatment } & \multicolumn{5}{|c|}{ After treatment } \\
\hline & $10 \mathrm{~mL}$ & $20 \mathrm{~mL}$ & $30 \mathrm{~mL}$ & $40 \mathrm{~mL}$ & $50 \mathrm{~mL}$ & $10 \mathrm{~mL}$ & $20 \mathrm{~mL}$ & $30 \mathrm{~mL}$ & $40 \mathrm{~mL}$ & $50 \mathrm{~mL}$ \\
\hline $\begin{array}{l}\text { Amplitude of } \\
\text { relaxation }(\mathrm{mm} \mathrm{Hg})\end{array}$ & $\begin{array}{c}18 \\
(8-28)\end{array}$ & $\begin{array}{c}24 \\
(11-52)\end{array}$ & $\begin{array}{c}30 \\
(10-47)\end{array}$ & $\begin{array}{c}32 \\
(20-70)\end{array}$ & $\begin{array}{c}36 \\
(19-61)\end{array}$ & $\begin{array}{c}16 \\
(4-32)\end{array}$ & $\begin{array}{c}23 \\
(10-55)\end{array}$ & $\begin{array}{c}28 \\
(9-52)\end{array}$ & $\begin{array}{c}30 \\
(11-56)\end{array}$ & $\begin{array}{c}30 \\
(19-55)\end{array}$ \\
\hline $\begin{array}{l}\text { Duration of } \\
\text { relaxation (s) }\end{array}$ & $\begin{array}{c}8 \\
(4-15)\end{array}$ & $\begin{array}{c}11 \\
(6-19)\end{array}$ & $\begin{array}{c}13 \\
(9-18)\end{array}$ & $\begin{array}{c}13 \\
(10-18)\end{array}$ & $\begin{array}{c}12 \\
(8-19)\end{array}$ & $\stackrel{8}{8}$ & $\begin{array}{c}10 \\
(4-16)\end{array}$ & $\begin{array}{c}13 \\
(5-21)\end{array}$ & $\begin{array}{c}14 \\
(6-18)\end{array}$ & $\begin{array}{c}14 \\
(7-21)\end{array}$ \\
\hline $\begin{array}{l}\text { Residual pressure } \\
(\mathrm{mm} \mathrm{Hg})\end{array}$ & $\begin{array}{c}36 \\
(12-65)\end{array}$ & $\begin{array}{c}26 \\
(6-42)\end{array}$ & $\begin{array}{c}19 \\
(0-40)\end{array}$ & $\begin{array}{c}20 \\
(2-44)\end{array}$ & $\begin{array}{c}18 \\
(0-34)\end{array}$ & $\begin{array}{c}27 \\
(6-38)\end{array}$ & $\begin{array}{c}12 \\
(2-25)\end{array}$ & $\begin{array}{c}9 \\
(0-26)\end{array}$ & $\begin{array}{c}9 \\
(0-26)\end{array}$ & $\begin{array}{c}9 \\
(0-25)\end{array}$ \\
\hline Latency time (s) & $\begin{array}{c}1 \\
(0-2)\end{array}$ & $\begin{array}{c}1 \\
(0-3)\end{array}$ & $\begin{array}{c}2 \\
(0-4)\end{array}$ & $\begin{array}{c}1 \\
(0-3)\end{array}$ & $\begin{array}{c}1 \\
(0-3)\end{array}$ & $\begin{array}{c}1 \\
(0-3)\end{array}$ & $\begin{array}{c}1 \\
(0-3)\end{array}$ & $\begin{array}{c}1 \\
(0-3)\end{array}$ & $\begin{array}{c}1 \\
(0-2)\end{array}$ & $\begin{array}{c}1 \\
(0-5)\end{array}$ \\
\hline Descent angle ${ }^{(0)}$ & $\begin{array}{c}37 \\
(20-68)\end{array}$ & $\begin{array}{c}34 \\
(16-64)\end{array}$ & $\begin{array}{c}42 \\
(16-59)\end{array}$ & $\begin{array}{c}38 \\
(11-63)\end{array}$ & $\begin{array}{c}38 \\
(12-52)\end{array}$ & $\begin{array}{c}42 \\
(26-76)\end{array}$ & $\begin{array}{c}39 \\
(23-61)\end{array}$ & $\begin{array}{c}39 \\
(18-66)\end{array}$ & $\begin{array}{c}38 \\
(24-59)\end{array}$ & $\begin{array}{c}36 \\
(25-62)\end{array}$ \\
\hline Ascent angle ${ }^{(0)}$ & $\begin{array}{c}58 \\
(25-70)\end{array}$ & $\begin{array}{c}51 \\
(15-67)\end{array}$ & $\begin{array}{c}49 \\
(30-69) \\
\end{array}$ & $\begin{array}{c}44 \\
(24-62) \\
\end{array}$ & $\begin{array}{c}44 \\
(23-66)\end{array}$ & $\begin{array}{c}55 \\
(42-68) \\
\end{array}$ & $\begin{array}{c}50 \\
(16-64)\end{array}$ & $\begin{array}{c}52 \\
(16-61)\end{array}$ & $\begin{array}{c}53 \\
(42-72)\end{array}$ & $\begin{array}{c}49 \\
(31-81) \\
\end{array}$ \\
\hline
\end{tabular}

Friedman $(P>0.05)$.

\section{DISCUSSION}

The recovery rates observed in this study were similar to those reported by MOREIRA et al..$^{(14)}$, who obtained success in $64.4 \%$ of cases, by NOLAN et al. ${ }^{(15)}$, who reported remission in $49 \%$ and important improvement in $11 \%$ of cases, and by LOENINGBAUCKE $^{(10)}$, who reported recovery in $63 \%$ of chronically constipated children submitted to standard treatment.

Fecal soiling was observed in all children with poor outcome. LOENING-BAUCKE ${ }^{(9)}$, studying the factors that can influence the results of treatment in children with intestinal constipation and fecal soiling, mentioned that the children who did not recover reported more frequent soiling episodes per week at first evaluation than those who recovered. This suggests that soiling is associated with treatment failure, and can be an indicator of the severity of constipation, considering that it is secondary to fecal retention.

The anal basal pressure medians obtained before and after treatment were similar to those reported by many investigators for control children $^{(1,5,7,12,13,16,18)}$. Studies on the internal sphincter pressure of constipated children with or without soiling have reported contradictory results. Some authors recorded normal anal resting tone in constipated children, while others reported anal resting tone to be higher or lower in constipated children than in controls ${ }^{(2)}$. In the present study, a reduction in anal basal pressure occurred after therapeutic intervention. Most 
investigators observed no changes in the anal resting tone of children who recovered from constipation and soiling ${ }^{(4,12,13)}$.

In the same manometry, the amplitude and the duration of the relaxation during the "1- second rectal distention" were similar to those obtained during the " 10 - second rectal distention". On this basis, only one 1 or 10- second rectal distention can be evaluated to determine the amplitude and the duration of the relaxation. Considering the present results, it is preferable to evaluate only the " 1 - second rectal distention" since, in addition to this being a faster examination (a very important fact when children are being submitted to the exam), more reflexes tend to occur during this phase than during the " 10 - second rectal distention", although the difference is not statistically significant. The amplitude and the duration of the relaxation for the 30,40 and 50 $\mathrm{mL}$ volumes were similar, so that the number of insufflations could be reduced using only one of these three volumes. The value of 60 $\mathrm{mL}$ might be included since previous studies have shown significant differences between insufflations with 30 and $60 \mathrm{~mL}^{(5,6,17)}$. In the present study, with insufflation of the rectal balloon with $30 \mathrm{~mL}$ of air (considering the "1- second rectal distention" of manometry before treatment), we observed an amplitude of relaxation closely similar to that observed by STAIANO and Del GIUDICE ${ }^{(17)}$, and larger than that observed by LOENING-BAUCKE and YOUNOSZAI ${ }^{(5)}$ and LOENING-BAUCKE ${ }^{(6)}$. With insufflation with $50 \mathrm{~mL}$ of air (the "1- second rectal distention" of manometry before treatment), we obtained values closely similar to those reported by BOROWITZ et al. ${ }^{(3)}$, who demonstrated that functionally constipated children have lower amplitude of relaxation than controls. After standard treatment, amplitude of relaxation remained lower than in controls, as also reported by LOENING-BAUCKE and YOUNOSZAI ${ }^{(5)}$, LOENING-BAUCKE ${ }^{(6)}$ and DAVILA et al. ${ }^{(4)}$. With respect to the duration of relaxation, DAVILA et al. ${ }^{(4)}$ also reported that no change occurred after standard treatment.

The evaluation of the residual pressure, which was performed in order to study the external anal sphincter and other subtle modifications in relaxation such as changes in the latency time and descent and ascent angles showed no changes after therapeutic intervention.

It was concluded that the anal basal pressure decreased in children recovering from chronic functional constipation, suggesting that these children can have involuntary additional contraction of the anal sphincter, probably secondary to retention, to avoid the elimination of the hard, large and consequently painful stools. When this is corrected, the contraction disappears and the anal pressure decreases. Based on the literature, the relaxation reflex of normal children is different from that seen in constipated children, i.e., the amplitude is shorter in constipated than in normal children. We may conclude that the standard treatment did not provide the conditions necessary for the relaxation reflex of the constipated children to return to the values described for normal children.

Bigélli RHM, Fernandes MIM, Vicente YAMVA, Dantas RO, Galvão LC, Campos AD. Manometria anorretal em crianças com constipação intestinal crônica funcional. Arq Gastroenterol 2005;42(3)178-81.

RESUMO-Racional-A manometria é um exame bastante utilizado e bem reconhecido no diagnóstico diferencial da constipação intestinal crônica na criança. Os achados manométricos mais comumente verificados nas crianças com constipação intestinal crônica funcional são: hipotonia e hipertonia anal, contração paradoxal do esfíncter anal externo, habilidade diminuída do esfincter anal interno para relaxar durante a distensão retal, aumento da complacência e do limiar de sensibilidade retal, além de diminuição da contratilidade retal. Objetivo-Avaliar a pressão basal anal e o reflexo reto esfincteriano antes e após o tratamento convencional, para melhor entendimento dos mecanismos fisiopatológicos envolvidos na constipação intestinal crônica funcional na criança. Métodos -Compararam-se as manometrias anorretais realizadas antes e após tratamento, em 20 crianças de 4 a 12 anos com constipação intestinal crônica funcional com boa resposta terapêutica convencional. Resultados - Houve redução da pressão basal anal após o tratamento mas não ocorreram diferenças na manometria realizada antes e após tratamento quanto a amplitude e duração do relaxamento, pressão residual, tempo de latência e ângulos de subida e de descida. Conclusões -Concluiu-se que a pressão basal anal diminui na criança com constipação funcional com boa resposta à terapêutica convencional, mas este tratamento não proporcionou todas as condições necessárias para que o reflexo reto esfincteriano retornasse a valores descritos em crianças normais.

DESCRITORES - Manometria. Constipação. Reto, fisiologia. Ânus, fisiologia. Crianças.

\section{REFERENCES}

1. Arhan P, Faverdin C, Thouvenot J. Ano-rectal motility in sick children. Scand J Gastroenterol 1972;7:309-14.

2. Benninga MA, Büller HA, Heymans HS, Tygat GN, Taminiau JA. Is encopresis always the result of constipation? Arch Dis Child 1994;71:186-93.

3. Borowitz SM, Sutphen J, Ling W, Cox DJ. Lack of correlation of anorectal manometry with symptoms of chronic childhood constipation and encopresis. Dis Colon Rectum 1996;39:400-5.

4. Dávila E, De Rodrigues GG, Adrianza A, Pereira Y, Toro J, Gonzales I, Römer H. Utilidad del biofeedback en niños com encopresis. Comunición preliminar. Gen 1992;46:297-301.

5. Loening-Baucke VA, Younoszai MK. Abnormal and sphincter response in chronically constipated children. J Pediatr 1982;100:213-8.

6. Loening-Baucke VA. Abnormal rectoanal function in children recovered from chronic constipation and encopresis. Gastroenterology 1984;87:1229-304.

7. Loening-Baucke VA, Younoszai MK. Effect of treatment on rectal and sigmoid motility in chronic constipated children. Pediatrics 1984;73:199-205.

8. Loening-Baucke VA, Cruikshank, BM. Abnormal defecation dynamics in chronically constipated children with encopresis. J Pediatr 1986;108:562-6.

9. Loening-Baucke, VA. Factors determining outcome in children with chronic constipation and faecal soiling. Gut 1989;30:999-1006.

10. Loening-Baucke VA. Chronic constipation in children. Gastroenterology 1993;105:1557-64.
11. Meunier P, Mollard P, Marechal JM. Physiopathology of megarectum: the association of megarectum with encopresis. Gut 1976;17:224-7.

12. Meunier P, Marechal JM, De Beaujeu MJ. Rectoanal pressures and rectal sensitivity studies in chronic childhood constipation. Gastroenterology 1979;77:330-6.

13. Molnar D, Taitz LS, Urwin OM, Wales JKH. Anorectal manometry results in defecation disorders. Arch Dis Child 1983;58:257-61.

14. Moreira FL, Coelho CA, Maffei HV. Constipação intestinal crônica em crianças atendidas no ambulatório de gastroenterologia infantil da Faculdade de Medicina de Botucatu-UNESP (1977-1980). J Pediatr 1984;57:62-5.

15. Nolan T, Debelle G, Oberklaid F, Coffey C. Randomised trial of laxatives in treatment of childhood encopresis. Lancet 1991;338:523-7.

16. Schuster MM. Diagnostic value of anal sphincter pressure measurements. Hosp Pract 1973;8:115-22

17. Staiano A, Del Giudice E. Colonic transit and anorectal manometry in children with severe brain damage. Pediatrics 1994:94:169-73.

18. Sutphen J, Borowitz S, Ling W, Cox DJ, Kovatchev B. Anorectal manometric examination in encopretic-constipated children. Dis Colon Rectum 1997;40:1051-5. 